\title{
Saccharomonospora paurometabolica sp. nov., a moderately halophilic actinomycete isolated from soil in China
}

\author{
Wen-Jun Li, ${ }^{1}$ Shu-Kun Tang, ${ }^{1}$ Erko Stackebrandt, ${ }^{2}$ \\ Reiner M. Kroppenstedt, ${ }^{2}$ Peter Schumann, ${ }^{2}$ Li-Hua Xu ${ }^{1}$ \\ and Cheng-Lin Jiang ${ }^{1}$
}

Correspondence

Cheng-Lin Jiang

lihxu@ynu.edu.cn or

liact@yahoo.com

\begin{abstract}
${ }^{1}$ The Key Laboratory for Microbial Resources of the Ministry of Education, P. R. China, Laboratory for Conservation and Utilization of Bio-Resources, Yunnan Institute of Microbiology, Yunnan University, Kunming, Yunnan, China, 650091

${ }^{2} \mathrm{DSMZ}$ - Deutsche Sammlung von Mikroorganismen und Zellkulturen, Mascheroder Weg 1b, 38124 Braunschweig, Germany
\end{abstract}

\begin{abstract}
A novel, moderately halophilic actinomycete, strain YIM $90007^{\top}$, was isolated from a soil sample collected from the Xinjiang Province, China, and characterized. The optimum growth temperature of the strain was between 35 and $37^{\circ} \mathrm{C}$ and growth occurred optimally in $10 \%(\mathrm{w} / \mathrm{v})$ $\mathrm{NaCl}$. The cell wall of strain YIM $90007^{\top}$ contained meso-diaminopimelic acid. Whole-cell sugars were galactose, arabinose and ribose. The principal menaquinone was $\mathrm{MK}-9\left(\mathrm{H}_{4}\right)$, while MK- $9\left(\mathrm{H}_{2}\right)$ was found in smaller amounts. The phospholipids were phosphatidylinositol, phosphatidylglycerol, diphosphatidylglycerol, phosphatidylethanolamine and hydroxyphosphatidylethanolamine. The predominant cellular fatty acids were of the iso- and anteiso-branched and unbranched types; significant amounts of 2-hydroxy fatty acids were also found but 10-methyl-branched fatty acids were missing. The DNA G $+C$ content of strain YIM $900007^{\top}$ was $71 \mathrm{~mol} \%$. Phylogenetic analysis based on 16S rRNA gene sequences showed strain YIM $90007^{\top}$ to be closely related to Saccharomonospora halophila (98.7\% similarity). DNA-DNA hybridization revealed a relatedness of $53.8 \%$ between strain YIM $90007^{\top}$ and S. halophila DSM $44411^{\top}$. Based on physiological and biochemical characteristics, phylogenetic analysis (based on 16S rRNA gene sequences) and DNA-DNA relatedness, it is concluded that strain YIM $90007^{\top}$ represents a novel species of the genus Saccharomonospora, for which the name Saccharomonospora paurometabolica (type strain YIM $90007^{\top}=$ CCTCC AA001018 $^{\top}=\mathrm{CCRC}$ $16315^{\top}=$ DSM $44619^{\top}$ ) is proposed.
\end{abstract}

The genus Saccharomonospora (Nonomura \& Ohara, 1971) was created for actinomycetes producing predominantly single spores on aerial hyphae. The cell wall contains mesodiaminopimelic acid together with the sugars arabinose and galactose. At the time of writing, the genus embraces six species, namely, Saccharomonospora viridis (Nonomura \& Ohara, 1971), Saccharomonospora azurea (Hu, 1987), Saccharomonospora glauca (Greiner-Mai et al., 1988), Saccharomonospora cyanea ( $\mathrm{Hu}$ et al., 1988), Saccharomonospora xinjiangensis (Jin et al., 1998) and Saccharomonospora halophila (Al-Zarban et al., 2002); only the latter species is halophilic. During a study on halophilic actinomycetes, a

Published online ahead of print on 21 March 2003 as DOI 10.1099/ ijs.0.02633-0.

The GenBank/EMBL/DDBJ accession number for the 16S rDNA sequence of Saccharomonospora paurometabolica YIM $90007^{\top}$ is AF540959. halophilic strain, YIM $90007^{\mathrm{T}}$, was isolated from one soil sample from the Xinjiang Province, in the west of China.

Strain YIM $90007^{\mathrm{T}}$ was isolated on modified glycerol/ asparagine agar (Shirling \& Gottlieb, 1966) [ISP5 medium containing $20 \%(\mathrm{w} / \mathrm{v}) \mathrm{NaCl}$ and incubated at $28{ }^{\circ} \mathrm{C}$ for about 4 weeks. The strain was maintained on ISP2 and ISP5 agar slants containing $10 \% \mathrm{NaCl}$ at $4{ }^{\circ} \mathrm{C}$ and as glycerol suspensions $(20 \%, \mathrm{v} / \mathrm{v})$ at $-20^{\circ} \mathrm{C}$. Biomass for chemical and molecular systematic studies was obtained by growing in shake flasks (about 150 r.p.m.) of ISP2 medium broth containing $10 \% \mathrm{NaCl}$ at $28^{\circ} \mathrm{C}$ for 1 week. Cultural characteristics were determined after 4 weeks at $28^{\circ} \mathrm{C}$ by methods used in the International Streptomyces Project (ISP) (Shirling \& Gottlieb, 1966). Morphological properties, spores and mycelia were examined by light microscopy (Olympus microscope $\mathrm{BH}-2$ ) and scanning electron microscopy with a JEOL, model JSM5600LV. Media and procedures used for 


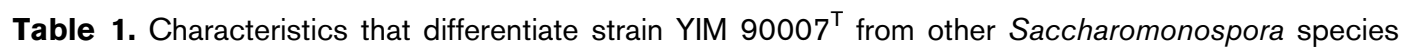

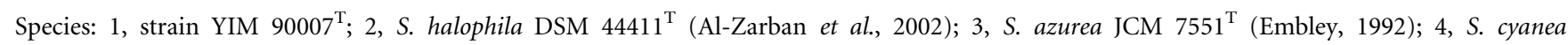
JCM $7552^{\mathrm{T}}$ (Embley, 1992); 5, S. glauca JCM $7444^{\mathrm{T}}$ (Embley, 1992); 6, S. viridis JCM 3036 ${ }^{\mathrm{T}}$ (Embley, 1992); 7, S. xinjiangensis CCTCC AA97021 ${ }^{\mathrm{T}}$ (Jin et al., 1998). +, Property present; -, property absent; D, presence of property doubtful; ND, not determined.

\begin{tabular}{|c|c|c|c|c|c|c|c|}
\hline Characteristics & 1 & 2 & 3 & 4 & 5 & 6 & 7 \\
\hline Aerial mycelium colour & White & $\begin{array}{l}\text { Light-blue } \\
\text { to greenish }\end{array}$ & Azure & Dark-blue & $\begin{array}{l}\text { Light- to } \\
\text { bluish-green }\end{array}$ & Green & Yellow-white \\
\hline Spore ornamentation & $\begin{array}{l}\text { Smooth or } \\
\text { wrinkled }\end{array}$ & Warty & Smooth & Warty & Warty & Warty & Smooth \\
\hline \multicolumn{8}{|c|}{ Growth on sole carbon source $(1 \%, \mathrm{w} / \mathrm{v})$ : } \\
\hline L-Arabinose & - & + & - & ND & + & - & ND \\
\hline Galactose & - & + & - & + & ND & - & ND \\
\hline Glucose & - & + & + & - & + & $\mathrm{D}$ & ND \\
\hline Mannitol & - & + & - & - & + & $\mathrm{D}$ & ND \\
\hline Melibiose & - & + & + & - & ND & ND & ND \\
\hline Rhamnose & - & + & - & ND & - & - & + \\
\hline Ribose & - & $\mathrm{D}$ & + & + & ND & ND & ND \\
\hline Xylose & - & - & + & $\mathrm{D}$ & + & - & + \\
\hline \multicolumn{8}{|l|}{ Growth in the presence of $\mathrm{NaCl}(\%)$ : } \\
\hline 0 & - & - & + & + & + & + & + \\
\hline 5 & + & - & + & - & - & - & - \\
\hline 7 & + & - & + & - & - & - & - \\
\hline 10 & + & + & - & - & - & - & - \\
\hline 20 & + & + & - & - & - & - & - \\
\hline 30 & - & + & - & - & - & - & - \\
\hline Optimum growth temperature $\left({ }^{\circ} \mathrm{C}\right)$ & $35-37$ & $28-30$ & $28-30$ & $28-30$ & $45-50$ & $45-50$ & 37 \\
\hline
\end{tabular}

determination of physiological features and carbon source utilization were those described by Shirling \& Gottlieb (1966) and Williams et al. (1989). Some results are indicated in comparison to those of other Saccharomonospora species (Table 1). Colour determination was done with colour chips from the ISCC-NBS Color-Name Charts Standard Samples no. 2106 (Kelly, 1964). Strain YIM 90007 developed well on most media tested (see species description). No diffusible pigments were produced.

Morphological features were observed on glycerol/asparagine agar (ISP5 medium) and yeast extract/malt extract (ISP2 medium) $[10 \%(\mathrm{w} / \mathrm{v}) \mathrm{NaCl}]$. Incubation time was for 4 weeks at $28^{\circ} \mathrm{C}$. Strain YIM $90007^{\mathrm{T}}$ had the typical characteristics of the genus Saccharomonospora. Aerial mycelium and substrate mycelium were well developed (Fig. 1). Single spores were borne on aerial mycelium, while some single spores were sporadically borne on the substrate mycelium. Spores were smooth or wrinkled.

The amino acid and sugar analysis of whole-cell hydrolysates followed procedures described by Staneck \& Roberts (1974). Polar lipids were extracted, examined by twodimensional TLC and identified using published procedures (Minnikin et al., 1984). Menaquinones were isolated using the methods of Minnikin et al. (1984) and separated by HPLC (Kroppenstedt et al., 1981; Kroppenstedt, 1982). Cellular fatty acid composition was determined as described by Sasser (1990). Cell walls of strain YIM $90007^{\mathrm{T}}$ contained meso-diaminopimelic acid. Whole-cell hydrolysates contained mainly galactose, arabinose and ribose. The predominant menaquinones were MK-9 $\left(\mathrm{H}_{4}\right)(90 \%)$ and MK-9( $\left.\mathrm{H}_{2}\right)(10 \%)$. The polar lipid extract contained phosphatidylinositol, phosphatidylglycerol, diphosphatidylglycerol, phosphatidylethanolamine and hydroxyphosphatidylethanolamine. Cellular fatty acids are indicated in the species description.

Extraction of genomic DNA and amplification of $16 \mathrm{~S}$ rDNA were done as described by Cui et al. (2001). Multiple alignments with sequences of a broad selection of

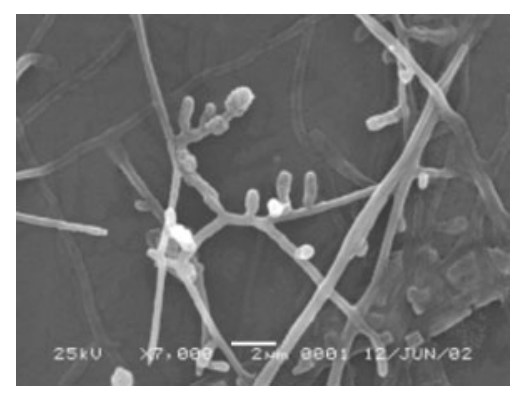

Fig. 1. Scanning electron micrograph of the spore chains of Saccharomonospora paurometabolica YIM $90007^{\top}$ grown on yeast extract/malt extract agar (ISP2 medium) containing $10 \%$ (w/v) $\mathrm{NaCl}$ for 28 days at $28^{\circ} \mathrm{C}$. Bar, $2 \mu \mathrm{m}$. 
Actinobacteria and calculations of levels of sequence similarity were carried out using CLUSTAL W 1.8 (Thompson et al., 1994). A phylogenetic tree was reconstructed using the neighbour-joining method of Saitou \& Nei (1987) from $K_{\text {nuc }}$ values (Kimura, 1980, 1983). The topology of the phylogenetic tree (Fig. 2) was evaluated by the bootstrap resampling method of Felsenstein (1985) with 1000 replicates. The almost-complete $16 \mathrm{~S}$ rDNA sequence of strain YIM $90007^{\mathrm{T}}$ was $1474 \mathrm{bp}$ long. The highest similarity values were found with sequences of members of the genus Saccharomonospora: except for S. halophila DSM $44411^{\mathrm{T}}$, displaying $98.7 \%$ similarity, none of the other type strains shared higher than $97 \cdot 0 \%$ sequence similarity with strain YIM $90007^{\mathrm{T}}$.

DNA for renaturation studies and determination of the base content of strain YIM $90007^{\mathrm{T}}$ was prepared following the method of Marmur (1961). The G $+C$ content was determined using the thermal denaturation method of Marmur \& Doty (1962). DNA-DNA hybridization was carried out according to described methods (De Ley et al., 1970; Huss et al., 1983; Jahnke,1992). The G + C contents of the genomic DNA from strain YIM $90007^{\mathrm{T}}$ and S. halophila DSM $44411^{\mathrm{T}}$ were 71 and $70 \mathrm{~mol} \%$, respectively. DNADNA reassociation similarity between strain YIM $90007^{\mathrm{T}}$ and S. halophila DSM $44411^{\mathrm{T}}$ indicated a moderate value of $53 \cdot 8 \%$ (repeated).

Based on phylogenetic, morphological and chemical data, strain YIM $90007^{\mathrm{T}}$ should be considered a member of the genus Saccharomonospora. It is only moderately related to S. halophila DSM $44411^{\mathrm{T}}$, as measured by DNA-DNA relatedness, and shows differences in chemotaxonomic properties, such as the presence of $\mathrm{MK}-8\left(\mathrm{H}_{4}\right)$ and the different fatty acid patterns in strain DSM $44411^{\mathrm{T}}$ (Al-Zarban et al., 2002). It also shows sufficient physiological and cultural differences to other Saccharomonospora

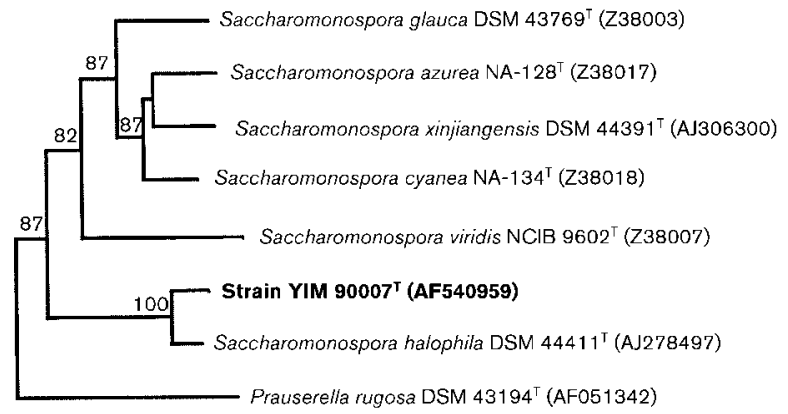

$1 \%$

Fig. 2. Phylogenetic dendrogram, obtained by distance matrix analysis of $16 \mathrm{~S}$ rDNA sequences, showing the position of strain YIM $90007^{\top}$ among its phylogenetic neighbours. Numbers at the branch nodes are bootstrap values, expressed as a percentage of 1000 replicates. Sequences of Amycolatopsis type strains were used as the root. Bar, $1 \%$ sequence divergence. species to justify the description of a new species, Saccharomonospora paurometabolica (type strain YIM $90007^{\mathrm{T}}$ ).

\section{Description of Saccharomonospora paurometabolica sp. nov.}

Saccharomonospora paurometabolica (pau.ro.me.ta.bo'li.ca. Gr. adj. pauros little; Gr. adj. metabolikos changeable; N.L. fem. adj. paurometabolica little changeable, referring to the poor utilization of carbon sources).

Aerial mycelium is well developed on yeast extract/malt extract agar (ISP2 medium), glycerol/asparagine agar (ISP5 medium), nutrient agar and Czapek's agar; moderate on oatmeal agar (ISP3 medium) and poor on inorganic salt/ starch agar (ISP4 medium) and potato agar. White aerial mycelium on all media, except for a green-yellow mycelium on nutrient agar. Sporulation is good on ISP2, ISP5, nutrient agar and Czapek's agar media, moderate on ISP3 medium and poor on ISP4 medium. Substrate mycelium is well developed on most test media. Colour is deep orangeyellow (ISP2), light yellow-brown (nutrient agar), light yellow-orange (potato agar) or white (ISP4, ISP5 and Czapek's agar). Non-motile single spores with smooth or wrinkled surface, borne on aerial mycelium; some single spores borne on substrate mycelium. Optimum growth temperature is between 35 and $37^{\circ} \mathrm{C}$. Optimum growth concentration of $\mathrm{NaCl}$ is $10 \%(\mathrm{w} / \mathrm{v})$. Positive only for nitrate reduction. Negative for milk peptonization and coagulation, gelatin liquefaction, growth in cellulose, $\mathrm{H}_{2} \mathrm{~S}$ and melanin production, starch hydrolysis and urease production. The range of carbon utilization could not be determined because of negative reactions caused by extremely poor growth in basal media. The cell wall contains meso-diaminopimelic acid. Whole-cell hydrolysates contain mainly galactose, arabinose and ribose. The only menaquinones are MK-9 $\left(\mathrm{H}_{2}\right)(10 \%)$ and MK-9 $\left(\mathrm{H}_{4}\right)(90 \%)$, and the phospholipids are phosphatidylinositol, phosphatidylglycerol, diphosphatidylglycerol, phosphatidylethanolamine and hydroxyphosphatidylethanolamine. Predominant cellular fatty acids are $\mathrm{C}_{16: 0}(20 \cdot 7 \%)$, iso- $\mathrm{C}_{16: 0}(11 \cdot 2 \%)$ and $\mathrm{C}_{18: 1}(44 \cdot 3 \%)$; smaller amounts $(>1 \%)$ are iso- $\mathrm{C}_{15: 0}$ $(1 \cdot 0 \%)$, iso- $\mathrm{C}_{16: 1}(1 \cdot 1 \%)$, iso- $\mathrm{C}_{17: 0}(1 \cdot 2 \%)$, iso- $\mathrm{C}_{17: 1}$ $(1 \cdot 4 \%)$, anteiso- $\mathrm{C}_{17: 0}(3 \cdot 1 \%), \mathrm{C}_{16: 1}(4 \cdot 4 \%), \mathrm{C}_{18: 0}$ $(3 \cdot 0 \%), 2$-hydroxy-anteiso- $\mathrm{C}_{15: 0}(4 \cdot 8 \%)$ and 2-hydroxyiso- $\mathrm{C}_{16: 0}(1 \cdot 7 \%)$.

Type strain is YIM $90007^{\mathrm{T}}\left(=\right.$ CCTCC AA001018 ${ }^{\mathrm{T}}=$ CCRC $\left.16315^{\mathrm{T}}=\mathrm{DSM} 44619^{\mathrm{T}}\right)$. Its DNA G $+\mathrm{C}$ content is $71 \mathrm{~mol} \%$. Isolated from saline soil collected from the Xinjiang Province, in the west of China.

\section{Acknowledgements}

This research was supported by the Ministry of Science and Technology, P. R. China (project no. 2001CCC00600), the National Natural Science Foundation of China (project no. 30270004), the Yunnan Provincial Natural Science Foundation (project no. 20001C001Q), the Yunnan Education Commission Foundation (project nos 01111134 and 02QJ077) and the Key Laboratory for Microbial Resources of the Ministry of Education, P. R. China. 


\section{References}

Al-Zarban, S. S., Al-Musallam, A. A., Abbas, I., Stackebrandt, E. \& Kroppenstedt, R. M. (2002). Saccharomonospora halophila sp. nov., a novel halophilic actinomycete isolated from marsh soil in Kuwait. Int J Syst Evol Microbiol 52, 555-558.

Cui, X.-L., Mao, P.-H., Tseng, M., Li, W.-J., Zhang, L.-P., Xu, L.-H. \& Jiang, C.-L. (2001). Streptimonospora salina gen. nov., sp. nov., a new member of the family Nocardiopsaceae. Int J Syst Evol Microbiol 51, 357-363.

De Ley, J., Cattoir, H. \& Reynaerts, A. (1970). The quantitative measurement of DNA hybridization from renaturation rates. Eur J Biochem 12, 133-142.

Embley, T. M. (1992). The family Pseudonocardiaceae. In The Prokaryotes, 2nd edn, pp. 1188-1213. Edited by A. Balows, H. G. Trüper, M. Dworkin, W. Harder \& K. H. Schleifer. New York: Springer.

Felsenstein, J. (1985). Confidence limits on phylogenies: an approach using the bootstrap. Evolution 39, 783-791.

Greiner-Mai, E., Korn-Wendisch, F. \& Kutzner, H. J. (1988). Taxonomic revision of the genus Saccharomonospora and description of Saccharomonospora glauca sp. nov. Int J Syst Bacteriol 38, 398-405.

Hu, R. (1987). Saccharomonospora azurea sp. nov., a new species from soil. Int J Syst Bacteriol 37, 60-61.

Hu, R., Lin, C. \& Guizhen, W. (1988). Saccharomonospora cyanea sp. nov. Int J Syst Bacteriol 38, 444-446.

Huss, V. A. R., Festl, H. \& Schleifer, K.-H. (1983). Studies on the spectrophotometric determination of DNA hybridization from renaturation rates. Syst Appl Microbiol 4, 184-192.

Jahnke, K.-D. (1992). BASIC computer program for evaluation of spectroscopic DNA renaturation data from GILFORD SYSTEM 2600 spectrophotometer on a PC/XT/AT type personal computer. J Microbiol Methods 15, 61-73.

Jin, X., Xu, L.-H., Mao, P.-H., Hseu, T.-H. \& Jiang, C. L. (1998). Description of Saccharomonospora xinjiangensis sp. nov. based on chemical and molecular classification. Int J Syst Bacteriol 48, 1095-1099.

Kelly, K. L. (1964). Inter-Society Color Council-National Bureau of Standards Color-Name Charts Illustrated with Centroid Colors. Washington, DC: US Government Printing Office.

Kimura, M. (1980). A simple method for estimating evolutionary rates of base substitutions through comparative studies of nucleotide sequences. J Mol Evol 16, 111-120.
Kimura, M. (1983). The Neutral Theory of Molecular Evolution. Cambridge: Cambridge University Press.

Kroppenstedt, R. M. (1982). Separation of bacterial menaquinones by HPLC using reverse phase (RP 18) and a silver loaded ion exchanger as stationary phases. J Liq Chromatogr 5, 2359-2387.

Kroppenstedt, R. M., Korn-Wendisch, F., Fowler, V. J. \& Stackebrandt, E. (1981). Biochemical and molecular genetic evidence for transfer of Actinoplanes armeniacus into the family Streptomycetaceae. Zentbl Bakteriol Mikrobiol Hyg 1 Abt Orig C 2, 254-262.

Marmur, J. (1961). A procedure for the isolation of deoxyribonucleic acid from microorganisms. J Mol Biol 3, 208-218.

Marmur, J. \& Doty, P. (1962). Determination of the base composition of deoxyribonucleic acid from its thermal denaturation temperature. J Mol Biol 5, 109-118.

Minnikin, D. E., O'Donnell, A. G., Goodfellow, M., Alderson, G., Athalye, M., Schaal, K. P. \& Parlett, J. H. (1984). An integrated procedure for the extraction of isoprenoid quinones and polar lipids. J Microbiol Methods 2, 233-241.

Nonomura, H. \& Ohara, Y. (1971). Distribution of actinomycetes in soil. X. New genus and species of monosporic actinomycetes. J Ferment Technol 49, 895-903.

Saitou, N. \& Nei, M. (1987). The neighbor-joining method: a new method for reconstructing phylogenetic trees. Mol Biol Evol 4, 406-425.

Sasser, M. (1990). Identification of bacteria by gas chromatography of cellular fatty acids. USFCC Newsl 20, 16.

Shirling, E. B. \& Gottlieb, D. (1966). Methods for characterization of Streptomyces species. Int J Syst Bacteriol 16, 313-340.

Staneck, J. L. \& Roberts, G. D. (1974). Simplified approach to identification of aerobic actinomycetes by thin-layer chromatography. Appl Microbiol 28, 226-231.

Thompson, J. D., Higgins, D. G. \& Gibson, T. J. (1994). CLUSTAL W: improving the sensitivity of progressive multiple sequence alignment through sequence weighting, position-specific gap penalties and weight matrix choice. Nucleic Acids Res 22, 4673-4680.

Williams, S. T., Goodfellow, M. \& Alderson, G. (1989). Genus Streptomyces Waksman and Henrici 1943, 339 ${ }^{\mathrm{AL}}$. In Bergey's Manual of Systematic Bacteriology, vol. 4, pp. 2463-2468. Edited by S. T. Williams, M. E. Sharpe \& J. G. Holt. Baltimore: Williams \& Wilkins. 